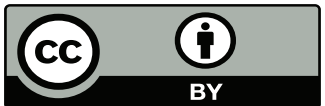

Hanne Tiikkaja ${ }^{a}$, Heikki Liimatainen ${ }^{b}$

\title{
Liikenteen ympäristövaikutusten vähentäminen kulkutapavalintojen muutosten avulla eri tulo- ja perheryhmissä
}

\begin{abstract}
Reducing environmental impact of transport by changing transport mode choices in different income and family groups

In this paper, we analyse if it is possible to reduce the environmental impact of travel by changing transport mode choices by those who use car a lot. The research questions are: I) How much do people in different family and income groups travel with different modes? and 2) How much would the total number of car trips decrease if the amount of car trips was limited among the people who make at least four car trips a day and these trips were assumed to be made using a sustainable mode of transport? The analyses are based on Finnish National Travel Survey conducted in 2016. The respondents are divided into I 5 groups based on their household income and family status. The results indicate that people living in higher income households travel more with car, but they are also found to recognise that an alternative transport mode for a car trip is available more often than people living in lower income households. This suggests that people living in lower income households use car more often for only mandatory trips. According to three scenarios created, there is a potential of 25 percent to reduce car trips by making changes in everyday travel.
\end{abstract}

Keywords: transport mode, car use, environmental impact

\section{Johdanto}

Ilmastonmuutoksen hillitsemiseksi vaaditaan nopeita toimia monilla eri aloilla. Yksi merkittävistä kasvihuonekaasupäästöjen lähteistä on liikenne, joka aiheuttaa noin 40 prosenttia taakanjakosektorin päästöistä Suomessa (Ympäristöministeriö 2017). Euroopan unionissa (EU) kasvihuonekaasupäästöt jaotellaan päästökauppasektorille, taakanjakosektorille, maankäyttösektorille ja kansainvälisen lento- ja meriliikenteen päästöihin. Taakanjakosektorin päästöt sisältävät kasvihuonekaasupäästöt energiankäytöstä, teollisuusprosesseista, liuottimista, maataloudesta ja päästökauppaan sisältymättömistä jätteistä. (Lindroos \& Ekholm 2016) Ilmastopolitiikan tavoitteeksi on asetettu

${ }^{a}$ Liikenteen tutkimuskeskus Verne, Tampereen yliopisto, hanne.tiikkaja@tuni.fi

b Liikenteen tutkimuskeskus Verne, Tampereen yliopisto, heikki.liimatainen@tuni.fi 
liikenteen päästöjen puolittaminen vuoden 2005 tasosta vuoteen 2030 mennessä. (Ympäristöministeriö 2017) Liikenteen ympäristövaikutusten vähentämiseksi voidaan tunnistaa kolme keinoa: ajoneuvotekniset keinot, polttoaineisiin liittyvät keinot sekä matkustussuoritteen vähentäminen (DeCicco 2013). Liikkumistottumuksia muuttamalla voidaan vähentää liikenteen ympäristövaikutuksia mahdollisesti nopeammin kuin esimerkiksi ajoneuvotekniikkaan liittyvillä ratkaisuilla (Donald ym. 2014), ja erilaiset murroskohdat, kuten muutokset liikenteen palvelutarjonnassa tai käytettävissä olevassa infrastruktuurissa, tarjoavat mahdollisuuden hyväksyttäviin liikkumistottumusten muutoksiin (Marsden ym. 2020). Liikkumistottumusten muutoksista kiinnostavaa on erityisesti henkilöautomatkojen vähentäminen.

Ihmisten ympäristöasenteet vaikuttavat arkiliikkumisen valintoihin. Hirvosen ja Vanhatalon (2018) mukaan ympäristömyönteinen asenne ei kuitenkaan tarkoita sitä, että ihmiset tekisivät ympäristön kannalta vastuullisia valintoja. Tätä voi selittää esimerkiksi arkikäyttäytymisen rutiinisidonnaisuus (Hirvonen \& Vanhatalo 2018). Tämän tutkimuksen avulla haluamme osoittaa, että ihmiset voivat joukkoliikennetarjonnan, hyvien kävely- ja pyöräreittien olemassaolon, palveluiden sijainnin ja henkilökohtaisten rajoitteiden puitteissa tehdä kestäviä valintoja arkiliikkumisessaan, ja että yksittäisten valintojen merkitys liikenteen ympäristövaikutuksiin on Suomessa välitön ja merkittävä. Tutkimus liittyy sekä liikenteen ympäristövaikutusten tutkimukseen että liikkumisen tasa-arvoa käsittelevään tutkimuskenttään.

Liikkumistottumuksia tarkastellaan usein sosiaalisen tasa-arvon ja hyvinvoinnin näkökulmasta (mm. Lucas 2012; Lucas ym. 2016; De Vos \& Witlox 2017). Tuloja on käytetty laajasti mittarina muun muassa liikennehaitan olemassaololle sekä liikenteen sosiaalisen tasaarvon ilmentymiselle (Cui ym. 2020). Liikennehaitta (transport disadvantage) tarkoittaa liikkumiseen liittyviä yleisiä ongelmia kulkutavasta riippumatta (Delbosc \& Currie 2011). Liikennehaitta voi syntyä muun muassa autottomuudesta, huonoista julkisen liikenteen palveluista tai suurista liikkumisen kustannuksista (Lucas 2012). Hyvinvoinnin ja liikkumisen suhdetta tarkasteltaessa fokus on pääosin ollut niissä väestöryhmissä, joiden liikkumisessa voidaan tunnistaa päivittäisen liikkumistarpeen täyttämistä estäviä rajoitteita. Ympäristövaikutusten vähentämisen kannalta liikkumista on kuitenkin tarkasteltava siitä näkökulmasta, missä väestöryhmissä henkilöautoilua olisi mahdollista ja oikeudenmukaista vähentää.

Tämän tutkimuksen tavoitteena on arvioida, kuinka paljon kulkutapamuutoksilla on mahdollista edistää kestävää liikennettä ja tukea ilmastopolitiikan tavoitteiden toteutumista liikenteessä. Kestävä liikenne ottaa huomioon suppeammassa näkökulmassa liikenteen ympäristövaikutukset ja resurssienkäytön, kun taas laajemmassa merkityksessä kestävä liikenne huomioi myös liikenteen sosiaaliset ja taloudelliset vaikutukset. Kestävän kehityksen tavoitteena on kehitys, jonka avulla voidaan tyydyttää nykyiset tarpeet ilman, että vaarannetaan tulevien sukupolvien mahdollisuutta tyydyttää omat tarpeensa. (Zhao ym. 2020) Tutkimuskysymykset ovat: 1) Kuinka paljon eri tulo- ja perheryhmiin kuuluvat matkustavat eri kulkutavoilla? ja 2) Kuinka paljon henkilöautomatkojen kokonaismäärä vähenisi, jos päivittäin vähintään neljä henkilöautomatkaa tekevien henkilöautomatkamäärää rajoitettaisiin ja oletettaisiin nämä matkat kestävämmillä kulkutavoilla tehdyiksi? Seuraavassa luvussa esitämme tutkimuksen taustaa kirjallisuuden avulla. Luvussa 3 esittelemme tarkemmin tutkimusaineistona käytetyn valtakunnallisen henkilöliikennetutkimuksen vuodelta 2016, analyysia varten aineistoon tehdyt rajaukset sekä tutkimusmenetelmät. Vastaajat jaettiin perhe- ja tuloryhmiin siten, että tarkasteltavia ryhmiä oli yhteensä 15 . Tutkimusmenetelmänä käytimme ristiintaulukointia, ja loimme aineiston avulla kolme erilaista skenaariota, joissa henkilöautolla tehtyjen matkojen määrï rajoitettiin. Analyysien avulla tutkimme, miten liikkumistottumuksen vaihtelevat eri tulo- ja perheryhmissä ja miten henkilöautolla tehtyjen matkojen vähentäminen paljon henkilöautolla liikkuvien ryhmissä vaikuttaisi henkilöautomatkojen kokonaismäärään. Luvussa 5 teemme päätelmät tuloksista ja keskustelemme niiden merkityksestä sekä jatkotutkimustarpeista. 


\section{Taustaa}

\section{Neliporrasmallilla voidaan havainnollistaa matkapäätöksiä}

Liikenteen käsitetään usein olevan johdettua kysyntää, mikä tarkoittaa sitä, että liikenteen kysyntä riippuu muiden tekijöiden kysynnästä. Matkan tarve syntyy usein toisen aktiviteetin, tuotteen tai palvelun tarpeesta, mutta lopputuloksena myös liikenteelle syntyy kysyntää. (Yen ym. 2019) Esimerkiksi tarve hankkia ruokaa aiheuttaa syyn matkustaa kauppaan, ja siten ruuan kysyntä synnyttää kysyntää myös liikenteelle. Liikenteellä onkin suuri merkitys sekä itsessään että muita elämän osa-alueita mahdollistavana tekijänä (DeCicco 2013). Liikenne mahdollistaa yhteiskunnan toiminnan sekä toimii ihmisten hyvinvoinnin välillisenä osana, sillä liikenteen avulla ihmisten on mahdollista päästä kohteisiin, jotka eivät ole oman elinpiirin välittömässä läheisyydessä. Lisäksi liikenne itsessään on suuri toimiala ja tuottaa hyvinvointia muun muassa työllisyyden kautta (Pöllänen ym. 2015).

Ihminen tekee ennen matkaa erilaisia päätöksiä, jotka lopulta johtavat matkustustapahtumaan. Liikenteen mallintamisessa käytetään usein neliporrasmallia, jossa ihmisen oletetaan tekevän portaittain neljä päätöstä matkaan liittyen. Neliporrasmalli mukailee tyypillistä liikennemallin rakennetta, jossa otetaan huomioon sekä liikenteen kysyntä että liikenneverkon tarjonta (Bliemer ym. 2017). Neliporrasmallia on hyödynnetty Suomessa esimerkiksi Kuopion alueen liikennemallissa (Kalenoja \& Keränen 2012), Tampereella TALLI-mallissa (Tampere 2014) sekä pääkaupunkiseudun työssäkäyntialueen mallinnuksessa (HELMET-malli) (HSL 2011).

Neliporrasmallissa ensimmäinen vaihe on päätös matkan tekemisestä, joka synnyttää matkatuotoksia malliin. Toisessa päätöksessä valitaan matkan määränpää, jolloin malliin saadaan tieto matkojen suuntautumisesta osa-alueiden välillä. Kolmas päätös on kulkutavan valinta ja viimeinen päätös reitin valinta, joiden avulla malliin saadaan tuotettua matkojen märä kulkutavoittain sekä liikenneverkon kuormitus. (Kalenoja ym. 2008) Neliporrasmallissa liikenteen ympäristövaikutusten kannalta erityisen kiinnostavia tekijöitä ovat matkapäätös sekä päätös kulkutavasta. Nordfjærnen ym. (2016) mukaan liikenteen ympäristövaikutuksia voidaan vähentää vähentämällä henkilöautolla tehtyjä matkoja tai vaihtamalla matkan kulkutapaa henkilöautosta joukkoliikenteellä, kävellen tai pyörällä tehtäväksi.

\section{Matkamäärien vähentäminen}

Liikennejärjestelmän tehokkuuden parantamisen tavoitteena on, että yhdyskuntarakennetta ja joukkoliikennettä kehittämällä henkilöautolla yksin ajettujen matkojen määrä vähenee ja henkilöautosuoritteen kasvu kaupunkiseuduilla pysähtyy väestönkasvusta huolimatta (Ympäristöministeriö 2017). Matkamäärien vähentämistä ei kuitenkaan koeta hyväksi lähtökohdaksi arkiliikkumisen muutoksille, vaan tavoitteena on henkilöautomatkojen väheneminen. Esimerkiksi Isossa-Britanniassa paremman liikenteen kampanja (https:// bettertransport.org.uk) korostaa, että liikenteen vähentämisen tavoitteet ymmärretään usein väärin. Yleensä politiikassa käytetty sanamuoto liikenteen vähentämisestä viittaa juuri henkilöautoliikenteen vähentämiseen. Ihmisten vapautta liikkua tai liikkumisen kautta saavutettavia aktiviteetteja ei haluta rajoittaa tai vähentää. Usein kaupunkisuunnittelussa tähdätään tiiviiseen kaupunkirakenteeseen, jonka avulla etäisyydet kohteiden välillä ja siten matkojen pituudet lyhenevät, ja yhä useammat matkat on mahdollista tehdä pyörällä tai jalan auton sijaan. (CBT 2011) Myös liikenne- ja viestintäministeriön raportissa (2018) todetaan, että liikkumisen rajoittaminen ei ole mahdollista tai edes toivottavaa, vaan tavoitteena on ohjata ihmisiä liikkumaan kestävämmillä kulkutavoilla (LVM 2018).

Liikenteellä on välillistä arvoa hyvinvoinnin kannalta, koska usein matkapäätös liittyy matkan kohteena olevaan aktiviteettiin (Mokhtarian \& Salomon 2001), kuten tarpeeseen hankkia ruokaa tai siirtyä työpaikalle tekemään töitä. Matkoista saatu hyöty ei kuitenkaan ole 
ainoastaan aktiviteettien saavuttaminen. Liikkuminen ja matkojen tekeminen on ihmisille sisäsyntyistä ja luontaista toimintaa ja siten tärkeää itsessään. Liikkuminen voidaan tulkita yksilön resurssiksi, joka johtaa onnellisuuteen ja itsenäisyyden tunteeseen. (Shliselberg \& Givoni 2017) Näin ollen matkamäärien rajoittaminen ei ole toivottava kehityssuunta, vaan henkilöautomatkojen vähentäminen tulisi tapahtua kulkutapamuutosten avulla.

\section{Kulkutavan valinta}

Liikenteen ympäristövaikutusten vähentämiseksi auton käyttöä tulisi vähentää, ja suurempi osa matkoista tulisi kulkea joukkoliikenteellä, kävellen tai pyörällä (Nordfjærn ym. 2016; Heinen \& Mattioli 2019). Viime aikoina ihmisiä on kannustettu siihen, että vähintään osa matkoista vaihdettaisiin näillä kestävämmillä kulkutavoilla tehtäväksi eikä niinkään siihen, että kaikki matkat tulisi tehdä jollain muulla kulkutavalla kuin henkilöautolla. Ajatuksena on, että ihmiset matkustaisivat autolla vain osan matkoista ja hyödyntäisivät muita kulkutapoja niillä matkoilla, joilla nämä muut kulkutavat ovat riittävän kilpailukykyisiä auton kanssa. Useiden kulkutapojen hyödyntämisen uskotaan vähentävän autoriippuvaisuutta yhteiskunnassa. (Heinen \& Mattioli 2019)

Eri kulkutavat tarjoavat erilaisia hyötyjä liikkujalle, minkä vuoksi eri matkoille saatetaan valita eri kulkutapa. Kulkutavan valinta saattaa liittyä psykologisiin tekijöihin eikä välttämättä liikkumiseen välineenä siirtyä paikasta toiseen (Mokhtarian \& Salomon 2001; Lois \& López-Sáez 2009; Kaewkluengklom ym. 2017). Autolla liikkumisen hyödyiksi on tunnistettu muun muassa aikasäästöt, mukavuus, liikkumisen vapaus ja henkilökohtainen tila. Autosta on tullut monille tarpeellinen liikkumisväline valitun elämäntavan säilyttämiseksi. (Nilsson \& Küller 2000) Elämäntapa-termiä käytetään usein tutkimuksissa, vaikka sille ei ole tarkkaa määritelmää. Sosiologiassa elämäntavalla tarkoitetaan sitä, että yksilöt ilmaisevat sosiaalisen asemansa tiettyjen kulutukseen ja vapaa-aikaan liittyvien käyttäytymismallien avulla. Näitä käyttäytymismalleja muovaavat muun muassa uskomukset, kiinnostuksenkohteet ja asenteet. Liikkumisen osalta muun muassa asuinpaikan valinta ja autonomistus heijastavat elämäntapaa. Esimerkiksi perheellisten elämäntapaan saattaa sisältyä asuminen kauempana palveluista ja useamman auton omistaminen. (Van Acker ym. 2014) Autolla liikkumisen tarve nykyaikana liittyykin monesti asuinalueiden, työpaikkojen, koulujen ja palveluiden alueelliseen hajautumiseen (Cooper ym. 2001).

Bouscassen ym. (2018) mukaan joukkoliikenteen käytön motiivit poikkeavat auton käytön motiiveista ja ovat vaihtelevampia. Syyt käyttää joukkoliikennettä liittyvät paitsi palvelutasoon ja välineellisiin motiiveihin, myös näkemyksellisiin syihin. Henkilöt, jotka ovat ympäristötietoisia, voivat kokea suurempaa hyötyä joukkoliikenteen käyttämisestä ja pienempää hyötyä autolla matkustamisesta. (Bouscasse ym. 2018) Norjassa tehdyn tutkimuksen (Nordfjærn ym. 2016) mukaan pienituloiset ja matalasti koulutetut henkilöt kokevat joukkoliikenteen käyttökelpoisena vaihtoehtona henkilöautolle. Joukkoliikenteestä on siis yritettävä tehdä houkuttelevampaa myös niille, jotka yhdistävät sosiaalisen statuksen käytettyyn kulkutapaan. (Nordfjærn ym. 2016)

Kulkutavan vaihtamiseen henkilöautoilusta kestävämpien kulkutapojen käyttöön voidaan kannustaa niin sanotuilla push- tai pull-keinoilla. Push-keinoilla pyritään työntämään ihmisiä pois henkilöauton käytöstä esimerkiksi asettamalla autoilulle rajoituksia tai nostamalla autoilun kustannuksia, kun taas pull-menetelmillä halutaan vetää ihmisiä kohti kestävämpiä kulkutapoja esimerkiksi parantamalla joukkoliikenteen palvelutasoa tai alentamalla lippujen hintoja. (Nordfjærn ym. 2019)

\section{Talouden vaikutus henkilöautoiluun}

Bastianin ym. (2016) mukaan tällä vuosituhannella henkilöä kohden laskettujen henkilöautosuoritteiden kasvu on pysähtynyt tai jopa laskenut monissa länsimaissa. 
On ollut kiistanalaista, voidaanko henkilöautosuoritteiden pysähtymistä tai laskua selittää perinteisillä mittareilla, kuten bruttokansantuotteella, polttoaineen hinnalla tai maankäytön muutoksilla, vai onko kyseessä pikemmin elämäntapaan, asenteisiin ja preferensseihin liittyvä ilmiö (Bastian ym. 2016). Jälkimmäistä näkökulmaa tukee Collin (2020) tutkimus, jonka mukaan vuosituhannen vaihteessa aikuisikään tulleilla on suuria ikäluokkia vähemmän saastuttavat liikkumistottumukset, ja he ovat myös valmiimpia vaihtamaan henkilöautosta muihin kulkutapoihin. Bastianin (2017) mukaan kuitenkin monet asenteisiin, elämäntapaan ja preferensseihin liittyvät tekijät riippuvat taloudellisista tekijöistä, ja muutokset liikkumiseen liittyvissä asenteissa saattavat pikemmin olla seurausta auton käytön muutoksista.

Isossa-Britanniassa vuonna 2012 autolla tehtyjen matkojen määrän havaittiin olevan tulosidonnaista siten, että suurituloiset tekivät selvästi pienituloisia enemmän matkoja autolla, kun taas alimmissa tuloryhmissä tehtiin enemmän kävelymatkoja kuin ylemmissä tuloryhmissä. Suurituloiset myös asuivat useammin autollisessa kotitaloudessa. (Banister 2018) Detroitissa Yhdysvalloissa tehdyn tutkimuksen mukaan tietyllä asuinalueella asuvat hyvätuloiset ajavat pidempiä matkoja, kuluttavat enemmän polttoainetta ja aiheuttavat enemmän päästöjä kuin samalla asuinalueella asuvat pienituloiset (Kotval-K \& Vojnovic 2016). Isossa-Britanniassa henkilöautolla kuljettajana tehtyjen matkojen määrä on kymmenessä vuodessa (2002-2012) pudonnut 8 prosenttia, ja suurimmat henkilöautomatkojen määrien vähennykset ovat tapahtuneet suurituloisimmissa tulokymmenyksissä (Banister 2018). Auton omistamisen on havaittu vaikuttavan vahvasti valittuun kulkutapaan siten, että auton omistajat valitsevat useammin henkilöauton kulkutavakseen ja suhtautuvat vaihtoehtoisiin kulkutapoihin kielteisemmin (Sui Tao $y m$. 2019). Yhdysvalloissa pienituloiset käyttävät joukkoliikennettä enemmän kuin hyvätuloiset, ja joissain tapauksissa pienituloisilla ei ole muuta mahdollisuutta kuin käyttää joukkoliikennettä (Cui ym. 2020). Englannissa tehdyn tutkimuksen mukaan tulot vaikuttavat siihen, mitä kulkutapoja ihmisellä on käytettävissä ja vastaavasti mitä kulkutapoja matkoilla käytetään, mikä viittaa kulkutapojen saatavuuden epäarvoistumiseen (Heinen \& Mattioli 2019).

Bastianin ja Börjessonin (2015) sekä Bastianin ym. (2016) mukaan suuri osa Ruotsin, Saksan, Iso-Britannian, Australian, Yhdysvaltojen ja Ranskan henkilöauton käytön muutoksista voidaan selittää henkilöä kohden lasketun BKT:n sekä polttoaineen hinnan muutosten avulla. Bastianin ym. (2016) yksinkertaista, talouteen liittyvää auton käyttöä selittävää mallia on kuitenkin myös kritisoitu (Wadud \& Baierl 2017), mikä on johtanut keskusteluun henkilöautosuoritteen tasaantumista ja laskua selittävistä syistä (Bastian ym. 2017). Sampleton $y m$. (2017) toteavat, että muutokset tuloissa ja polttoainekustannuksissa sekä kaupungistumisen aste selittävät autolla liikkumisen määrää Isossa-Britanniassa. Edulliset polttoaineiden hinnat yhdistettynä taloudelliseen kasvuun saattaisivat johtaa lisääntyneeseen autolla liikkumiseen. (Sampleton ym. 2017) Bastianin ja Börjessonin (2015) mukaan henkilöautoilun kustannusten nousun myötä auton käytön vähentämiseen voidaan ohjata tiivistämällä yhdyskuntarakentamista, monipuolistamalla maankäyttöä sekä tehostamalla joukkoliikennetarjontaa.

\section{Menetelmät, aineisto ja rajaukset}

Tämän artikkelin tutkimusaineistona käytettiin valtakunnallisen henkilöliikennetutkimuksen vuoden 2016 aineistoa. Valtakunnallinen henkilöliikennetutkimus on toteutettu Suomessa vuodesta 1974 asti noin kuuden vuoden välein. Tutkimuksessa kerätään tietoa suomalaisten liikkumisesta matkapäiväkirjamuotoisena aineistonkeruuna. Alle 100 kilometrin matkoilta tietoa kerätään vastaajilta yhden tutkimuspäivän ajalta ja yli 100 kilometrin kotimaan ja ulkomaan matkoilta kolmelta viikolta. Tutkimuksen tavoitteena on kerätä perustietoa suomalaisten liikkumistottumuksista, matkojen syistä ja käytetyistä kulkutavoista, sekä 
luoda yleiskuva väestöryhmittäisestä ja alueellisesta liikkumisesta. (Liikennevirasto 2016)

Valtakunnallisen henkilöliikennetutkimuksen perusjoukkoon kuuluvat kaikki kuusi vuotta täyttäneet Suomessa asuvat ja henkikirjoitetut henkilöt (Liikennevirasto 2016). Vuoden 2016 tutkimuksen otokseen valittiin 65000 vastaajaa ja lisäotokseen 5000 vastaajaa. Osa vastaajista kuului valtakunnalliseen tutkimusotokseen ja osa alueellisiin otoksiin. Tutkimuksen vastausaste ennen lisäotosta oli 45 prosenttia. Kaikkiaan tutkimukseen vastasi 31000 vastaajaa, joista valtakunnallisen tutkimusosion vastaajia oli runsas 9300. (Pastinen ym. 2018)

Tätä artikkelia varten valtakunnallisen henkilöliikennetutkimuksen aineistosta valittiin analyysiin mukaan kaikki alle 100 kilometrin kotimaan matkat, joiden voidaan ajatella edustavan arkiliikkumista. Tutkimusaineistoa rajattiin siten, että tutkimukseen valittiin ainoastaan valtakunnalliseen tutkimukseen kuuluneet otoshenkilöt, eikä alueellisten lisäotosten henkilöitä sisällytetty analyysiin, jolloin otos ei painota tiettyjä alueita enemmän kuin toisia. Havainnoista valittiin kaikki yli 17-vuotiaat henkilöt, joten analyyseissä mukana olevat henkilöt ovat täysi-ikäisiä. Valitut henkilöt jaettiin ryhmiin perhe- ja tuloryhmittäin siten, että perheryhmiä muodostettiin kolme: 1) yksinasuvat, joiden perhekoko oli aineistossa yksi, 2) lapsettomat perheet, joiden perhekoko aineistossa oli suurempi kuin yksi, mutta alaikäisten lukumäärä perheessä oli nolla ja 3) lapsiperheet, joiden kotitaloudessa asui vähintään yksi alaikäinen lapsi. Tarkasteltavat kotitalouden bruttotuloryhmät olivat vuosituloittain alle 20000 euroa, 20 000-39 999 euroa, 40 000-59 999 euroa, 60 000-79 999 euroa ja yli 80000 euroa. Kaiken kaikkiaan tarkasteltavia ryhmiä oli 15.

Tarkasteltavissa ryhmissä havaintoja oli noin 350-1 000. Kolmessa ryhmässä havaintoja oli alle 100. Yksinasuvilla kahdessa suurituloisimmassa ryhmässä havaintoja oli vain vähän ( $n=61, n=20)$, mikä on havaittavissa myös tuloksissa. Erillistä alueellista rajausta ei tehty tarkasteltavien ryhmien suuren lukumäärän vuoksi. Alueellinen näkökulma nousee kuitenkin esiin analyysissä vaihtoehtoisten kulkutapojen tarkastelun kautta. Analyyseissä tarkasteltiin ryhmien keskimääräisiä matkalukuja kulkutavoittain, kulkutapajakaumia sekä henkilöautolla tehtyjen matkojen määriä. Tutkimustulokset on laskettu aineiston laajennuskertoimien avulla eli kaikki esitettävät tulokset on laajennettu väestötasolle. Analyysimenetelmänä käytettiin ristiintaulukointia.

Koska liikenteen päästöjen kannalta tärkeintä olisi pyrkiä vähentämään henkilöautoliikenteen kasvua, tarkasteluissa laskettiin, miten henkilöautolla paljon liikkuvien henkilöautomatkojen vähentäminen vaikuttaisi henkilöautomatkojen kokonaismääriin. Analyyseissa luotiin kolme erilaista skenaariota, joissa henkilöautolla runsaasti liikkuvien henkilöautomatkojen määrä vähenisi. Matkamäärät laskettiin siten, että nykyisessä tilanteessa toteutuneiden henkilöautomatkojen määrää rajoitettiin ja laskettiin, kuinka monta henkilöautomatkaa vähemmän skenaarion kuvaamassa tilanteessa syntyisi. Tätä uutta henkilöautomatkamäärää verrattiin nykytilanteeseen ja laskettiin henkilöautomatkojen prosentuaalinen vähenemä nykytilanteeseen nähden. Skenaariot luotiin edeltävien analyysien tuloksiin pohjautuen siten, että vain useita henkilöautomatkoja päivässä tehneiden henkilöautomatkoja rajoitettiin. Paljon henkilöautomatkoja tekeviin laskettiin ne, jotka tekevät vähintään neljä henkilöautomatkaa päivässä. Muilla kulkutavoilla liikkumista ei rajoitettu. Skenaarioiden lähtökohtana on, että matkat eivät jää tekemättä, vaan siirtyvät toisella kulkutavalla tehtäviksi tai matkat ketjutetaan uudelleen siten, että esimerkiksi kahdesta edestakaisesta matkasta syntyy kolmen matkan matkaketju.

\section{Tulokset}

Tarkasteltaville ryhmille laskettiin keskimääräinen matkaluku kulkutavoittain (kuva 1). Kaikissa perheryhmissä havaittiin, että pienituloisimmilla keskimääräinen matkaluku oli selvästi pienempi kuin suurituloisimmilla, mikä voi mahdollisesti selittyä esimerkiksi työmatkojen puutteella. Lapsiperheissä keskimääräinen matkaluku oli suurempi kuin 
lapsettomissa perheissä tai yksinasuvilla, mikä puolestaan selittyy kyyditsemismatkojen suuremmilla osuuksilla. Lapsiperheissä 14-18 prosenttia matkoista oli kyyditsemismatkoja, kun vastaava osuus yksinasuvilla oli 1-8 prosenttia ja lapsettomissa perheissä 6-9 prosenttia. Eri perheryhmissä tulojen ei havaittu vaikuttavan kyyditsemismatkojen osuuteen kaikista matkoista. Matkalukujen eroja tuloryhmittäin voidaan kuitenkin selittää ns. nollamatkalaisten avulla eli niiden vastaajien osuudella, jotka eivät olleet tehneet yhtään matkaa tutkimuspäivänä. Kaikissa perheryhmissä nollamatkalaisten osuus oli suurin pienimmässä tuloluokassa. Alle 20000 euron tuloryhmässä yksinasuvista 28 prosenttia ei tehnyt päivän aikana yhtään matkaa. Vastaavasti alle 20000 euron tuloryhmässä lapsettomissa perheissä 27 prosenttia ja lapsiperheissä 21 prosenttia ei tehnyt yhtään matkaa. Tulojen kasvaessa nollamatkalaisten osuus pieneni ja vähintään viisi matkaa tehneiden osuus kasvoi. Esimerkiksi lapsiperheissä yli 80000 euron tuloryhmässä nollamatkalaisia oli 8 prosenttia ja vähintään viisi matkaa tehneitä 28 prosenttia.

Kulkutapajakaumaa tarkasteltaessa havaitaan selvä ero henkilöauton käytössä alimmassa tuloryhmässä verrattuna muihin tuloryhmiin (kuva 2). Alle 20000 euron tuloryhmässä yksinasuvilla vain 37 prosenttia matkoista kuljettiin henkilöautolla, kun muissa tuloryhmissä (pl. suurin tuloryhmä) yli puolet matkoista tehtiin henkilöautolla. Lapsettomissa perheissä havaitaan samoin, että vain 52 prosenttia matkoista tehtiin henkilöautolla matalimmassa tuloryhmässä, kun muissa tuloryhmissä henkilöautomatkojen osuus oli 63-69 prosenttia. Lapsiperheiden ryhmässä kaikissa tuloryhmissä yli 60 prosenttia matkoista tehtiin henkilöautolla, mutta alimmassa tuloryhmässä henkilöautomatkojen osuus oli selvästi muita ryhmiä pienempi. Sen sijaan alimmassa tuloryhmässä henkilöauton käyttöä näyttäisi korvaavan jalankulku ja pyöräily, joiden kulkutapaosuus on suurin alle 20000 euron tuloryhmissä kaikissa perhetyypeissä.

Henkilöauton omistus eri ryhmissä on yhdenmukainen henkilöauton käytön kanssa. Alle 20000 euron tuloryhmässä yksinasuvista peräti 64 prosenttia asui kotitaloudessa, jossa ei ollut yhtään henkilöautoa. Vastaavasti alle 20000 euron tuloryhmässä lapsettomista

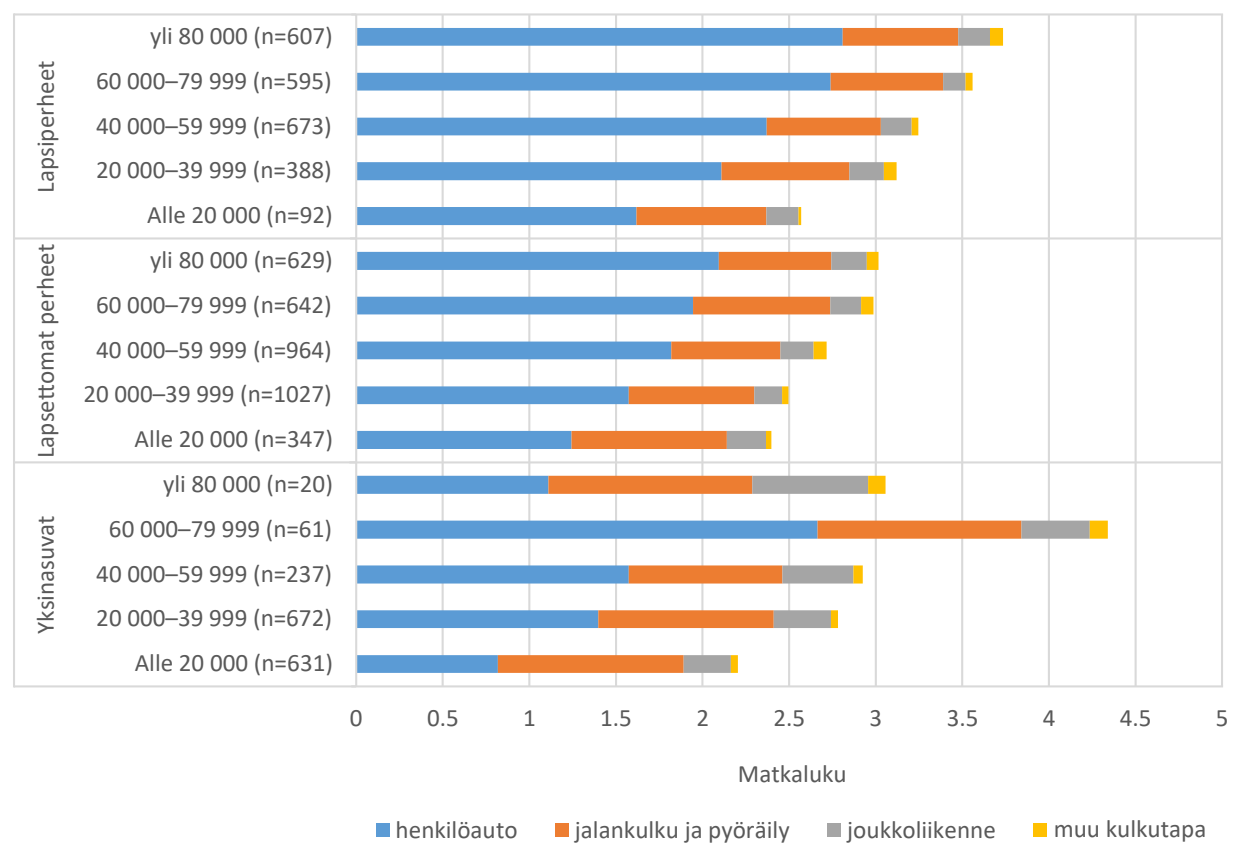

Kuva I. Keskimääräinen matkaluku kulkutavoittain perhe- ja tuloryhmittäin.

Figure I.Average trip number by transport mode in different household income and family status groups. 
perheistä 27 prosenttia ja lapsiperheistä 25 prosenttia asui autottomassa kotitaloudessa. Muissa tuloryhmissä henkilöauton omistus oli selvästi yleisempää kaikissa perheryhmissä. Lapsettomissa perheissä ja lapsiperheissä useamman kuin yhden henkilöauton omistus kotitaloudessa yleistyi huomattavasti tulojen kasvaessa.

Koska liikenteen päästöjen kannalta henkilöautosuoritteen vähentäminen on tärkeää, on hyvä tarkastella henkilöautomatkojen määrää eri perhe- ja tuloryhmissä. Yleisimmin henkilöautolla tehdään nolla tai kaksi matkaa päivässä. Henkilöautolla tehtyjen matkojen lukumäärän tarkastelu osoittaa, että pienituloisimmissa ryhmissä niiden osuus, jotka eivät ole tehneet päivässä yhtään henkilöautomatkaa, on suurin. Yksin asuvista alle 20000 euron tuloryhmässä 71 prosenttia ei tee yhtään henkilöautomatkaa. Yksinasuvista 20 000-39 999 euron tuloryhmässä 51 prosenttia ei tee yhtään henkilöautomatkaa päivässä ja 40 000-59 999 euron tuloryhmässä 44 prosenttia ei tee lainkaan henkilöautomatkoja päivässä. Lapsettomissa perheissä alimmassa tuloluokassa 59 prosenttia ei tee lainkaan henkilöautomatkoja päivässä, kun vastaava osuus 20 000-39 999 euron tuloluokassa on 46 prosenttia.

Lapsiperheissä ero nolla henkilöautomatkaa tehneiden osuudessa pienituloisimpien ja muiden tuloryhmien välillä ei ole yhtä huomattava kuin muissa perheryhmissä, mutta ero on kuitenkin olemassa. Alle 20000 euron tuloluokassa lapsiperheistä 41 prosenttia ei tehnyt lainkaan henkilöautomatkoja päivässä. 20 000-39 999 euron tuloluokassa vastaava osuus oli 36 prosenttia ja 40 000-59 999 euron tuloluokassa 31 prosenttia.

Kiinnostavaa on myös tarkastella paljon henkilöautomatkoja päivässä tekevien osuutta. Erityisen paljon henkilöautomatkoja tekeviä oli suurituloisten lapsiperheiden ryhmässä. Yli 60000 euroa tienaavissa lapsiperheissä lähes viidennes tekee vähintään viisi henkilöautomatkaa päivässä, kun taas alle 20000 euron tuloluokassa lapsiperheistä vain 3 prosenttia tekee vähintään viisi henkilöautomatkaa päivässä. Lapsettomissa perheissä 5-10 prosenttia tekee vähintään viisi henkilöautomatkaa päivässä siten, että suurituloisimmissa ryhmissä paljon matkoja tekevien osuus on suurempi. Lapsettomissa perheissä vähintään viisi henkilöautomatkaa päivässä tehneiden osuus oli pääasiassa 3-7 prosenttia.

Henkilöautomatkojen vähentämisen potentiaalia voidaan tutkia tarkastelemalla henkilöliikennetutkimuksessa vastaajilta kysyttyä vaihtoehtoisen kulkutavan olemassaoloa henkilöautolla kuljettajana tehdyillä matkoilla (kuva 3). Vaihtoehtoisen kulkutavan

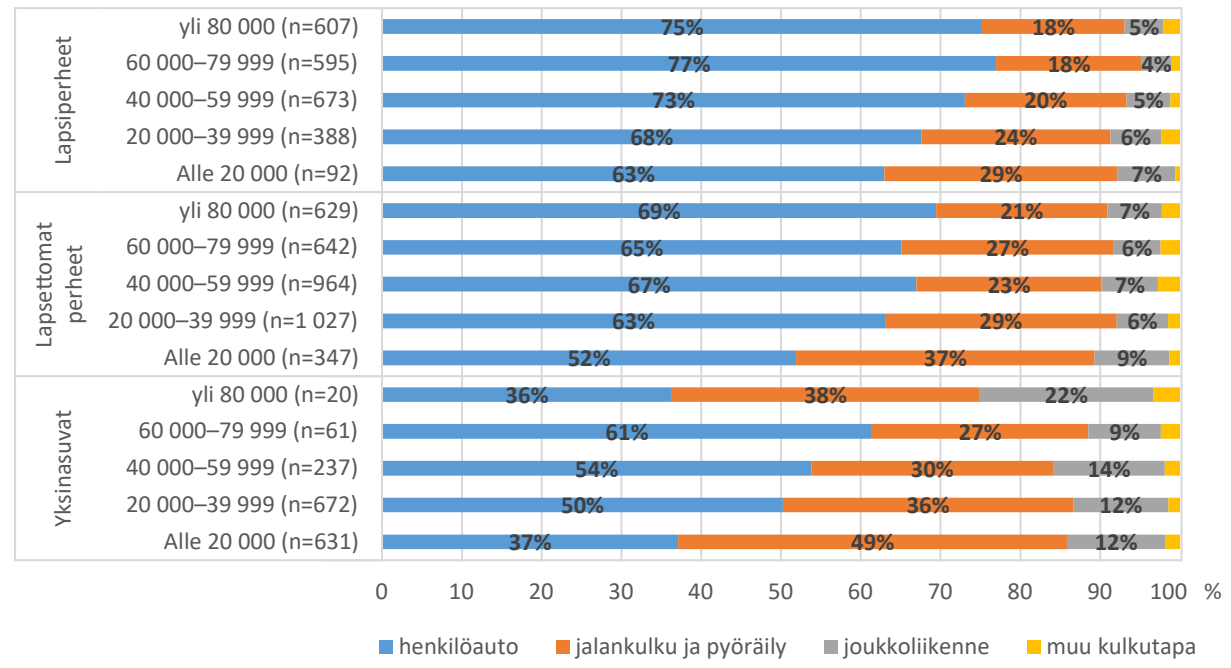

Kuva 2. Kulkutapajakauma perhe- ja tuloryhmittäin.

Figure 2. Modal split in different household income and family status groups. 
tunnistaminen kertoo myös siitä, millaisia kulkutapavaihtoehtoja asuinalueella on tarjoilla. Jos matka on lyhyt, kävely ja pyöräily ovat kulkutapavaihtoehtoja autolle monilla alueilla, mutta joukkoliikenne on vaihtoehto vain alueilla, joissa on toimivat joukkoliikenneyhteydet.

Vaihtoehtoisten kulkutapojen tarkastelussa havaitaan, että niissä ryhmissä, joissa vähintään viisi henkilöautomatkaa päivässä tehneiden osuus on suuri, myös vaihtoehtoinen kulkutapa henkilöautolla kuljettaja tehdylle matkalle on löytynyt useammin. Tämä tukee ajatusta, että pienituloisempien ryhmässä henkilöautolla tehdään vain välttämättömät matkat, kun taas suurituloisimpien ryhmässä, jossa henkilöautomatkoja tehdään enemmän, myös vähennyspotentiaalia henkilöautomatkoille on tunnistettavasti olemassa. Suurituloisimpien ryhmissä yli kolmannekselle henkilöautomatkoista oli tunnistettu vaihtoehtoinen kulkutapa. Pienituloisimpien ryhmässä vastaavasti vain noin joka viidennelle tai joka neljännelle henkilöautomatkalle olisi ollut valittavissa vaihtoehtoinen kulkutapa. Lapsiperheissä henkilöautomatkoille tunnistettiin hieman lapsettomia perheitä ja yksin asuvia harvemmin vaihtoehtoinen kulkutapa.

Edellisten analyysien pohjalta luotiin kolme erilaista skenaariota, joiden avulla tarkasteltiin, miten paljon henkilöautoa käyttävien henkilöautomatkojen rajoittaminen vaikuttaisi henkilöautolla tehtyjen matkojen kokonaismääriin. Skenaarioissa muilla kulkutavoilla tehtyjä matkamääriä ei rajoiteta, joten tarkoituksena ei ole vähentää liikkumista vaan siirtää osa matkoista kestävämmillä kulkutavoilla tehtäväksi. Koska paljon henkilöautoa käyttävissä ryhmissä henkilöautoilulle löytyi useammin myös vaihtoehtoinen kulkutapa, voidaan olettaa, että näissä ryhmissä on myös eniten mahdollisuuksia kulkutavan vaihtamiseksi toiseen. Seuraavassa tarkastelussa käsitellään kolmea erilaista skenaariota, joissa henkilöautolla runsaasti liikkuvien henkilöautomatkojen määrä vähenisi.

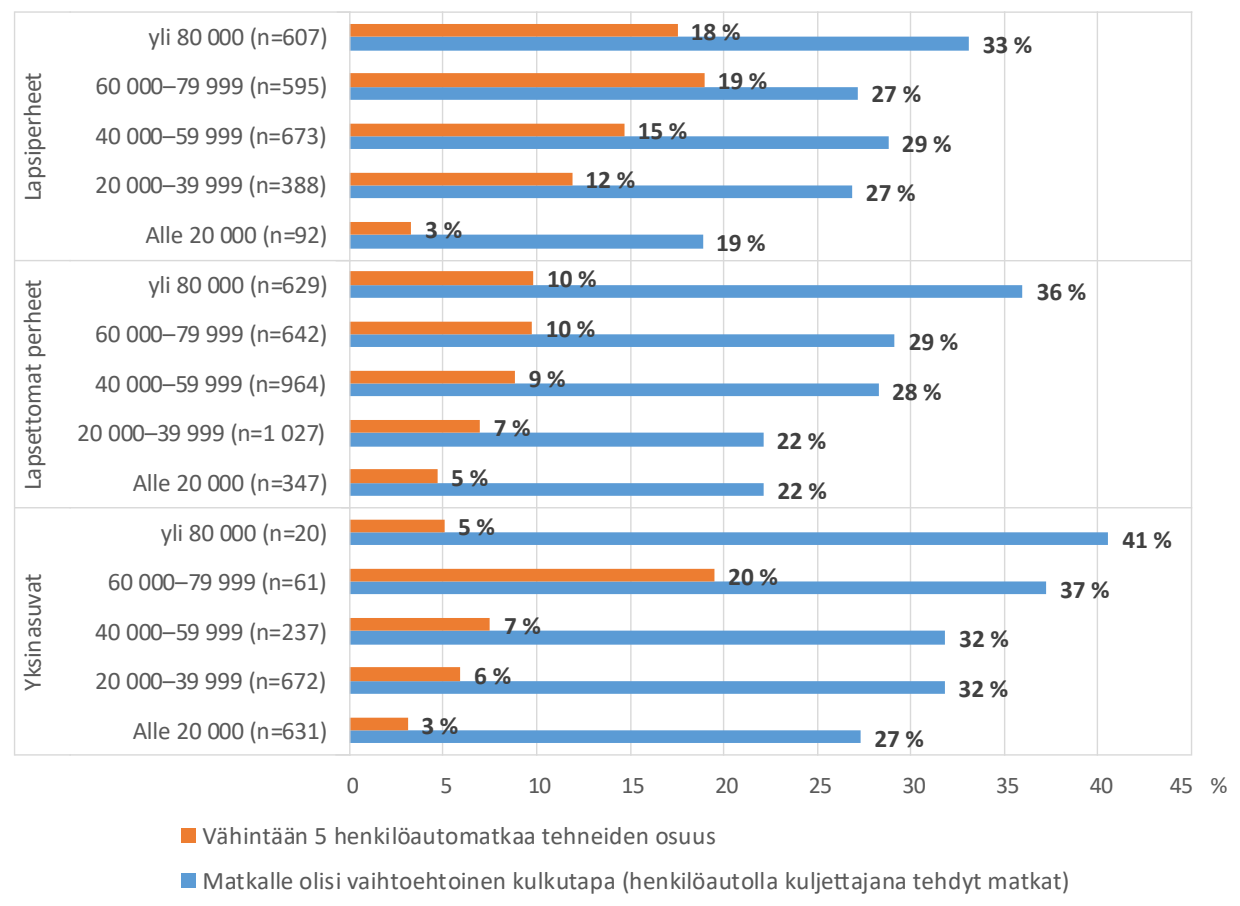

Kuva 3.Vaihtoehtoisen kulkutavan olemassaolo henkilöautolla kuljettajana tehdyillä matkoilla sekä vähintään viisi henkilöautomatkaa päivässä tehneiden osuudet perhe- ja tuloryhmittäin.

Figure 3.The share where an alternative transport mode for a trip made as a driver of a car was recognised and the share of those who had made at least five trips a day with a car in different household income and family status groups. 
- Nykyinen tilanne: Henkilöautomatkojen määrä 100 prosenttia

- Skenaario 1: Kaikkien vähintään viisi henkilöautomatkaa tehneiden henkilöautomatkamäärä rajataan neljään matkaan

- Skenaario 2: Kaikkien vähintään viisi henkilöautomatkaa tehneiden henkilöautomatkamäärä rajataan neljään matkaan ja neljä henkilöautomatkaa tehneiden henkilöautomatkamäärä rajataan kolmeen matkaan

- Skenaario 3: Kaikkien vähintään neljä henkilöautomatkaa tehneiden henkilöautomatkamäärä rajataan kolmeen matkaan

Nykyisessä laskennallisessa tilanteessa henkilöautomatkojen määrä on 100 prosenttia. Skenaariossa yksi kaikkien vähintään viisi henkilöautomatkaa tehneiden henkilöautomatkamäärä rajattiin neljään, jolloin henkilöautomatkojen kokonaismäärä aineistossa putosi 14 prosentilla. Skenaariossa kaksi yhdistettiin skenaarion yksi tulokset siihen, että neljä henkilöautomatkaa tehneiden henkilöautomatkamäärä rajoitettiin kolmeen matkaan. Tällöin aineiston henkilöautomatkamäärä putosi 20 prosenttia. Viimeinen, kolmas skenaario rajoittaa eniten henkilöautolla tehtyjä arkimatkoja, ja siinä kaikkien vähintään neljä henkilöautomatkaa tehneiden henkilöautomatkamäärä rajattiin kolmeen matkaan. Tällöin aineiston henkilöautomatkamäärä putosi 25 prosenttia.

Tarkastelussa ei kuitenkaan ole otettu huomioon sitä, että ihmiset liikkuvat usein matkaketjuissa. Jos aamulla on kulkutavaksi valittu auto, on luonnollista, että auton kanssa tehdään kaikki samaan matkaketjuun liittyvät matkat, vaikka jokin toinen kulkutapa olisi erilliselle matkalle ollut parempi vaihtoehto. Kaikki henkilöautomatkat eivät kuitenkaan liity suoraan matkaketjuun, vaan matkan kulkutavaksi on valittu henkilöauto muista syistä. Nämä matkat ovat niitä, joissa henkilöauton käytön vähennyspotentiaali on erityisesti olemassa.

\section{Johtopäätökset}

Liikenteen ympäristövaikutuksia voidaan pienentää vähentämällä henkilöautolla tehtyjä matkoja tai vaihtamalla matkan kulkutapa kestävämmäksi (Nordfjærn ym. 2016), mutta liikkumisen rajoittamista ei koeta toivottavaksi (LVM 2018). Tämän tutkimuksen tavoitteena oli tutkia, kuinka paljon pienillä kulkutapamuutoksilla on mahdollista edistää kestävää liikennettä ja tukea ilmastopoliittisia tavoitteita liikenteelle. Tutkimuskysymykset olivat: 1) Kuinka paljon eri tulo- ja perheryhmiin kuuluvat matkustavat eri kulkutavoilla? ja 2) Kuinka paljon henkilöautomatkojen kokonaismäärä vähenisi, jos päivittäin vähintään neljä henkilöautomatkaa tekevien henkilöautomatkamäärää rajoitettaisiin ja oletettaisiin nämä matkat kestävämmillä kulkutavoilla tehdyiksi?

Ensimmäiseen tutkimuskysymykseen vastasimme ristiintaulukoimalla 15 eri tulo- ja perheryhmään kuuluvien matkalukuja kulkutavoittain. Tulosten perusteella suurituloiset liikkuvat Suomessa enemmän kuin pienituloiset. Hyvätuloiset myös käyttävät henkilöautoa liikkumisessaan useammin kuin pienituloiset, jotka puolestaan liikkuvat kävellen suurituloisia enemmän. Banisterin (2018) mukaan Iso-Britanniassa korkeimmissa tuloryhmissä automatkojen määrä on suurempi ja kävelyn osuus pienempi kuin matalimmissa tuloryhmissä. Tulos on samansuuntainen tämän tutkimuksen tulosten kanssa. Tulosten perusteella olisi hyvä avata julkista keskustelua sosiaalisesta näkökulmasta liikenteen kestävyystavoitteisiin ja siitä, että suurituloisilla on selvästi enemmän mahdollisuuksia liikenteen ympäristövaikutusten vähentämiseksi kuin pienituloisilla. Näin ollen kaikki liikenteen kestävyyteen tähtäävät toimenpiteet tulisi arvioida myös sen mukaan, mihin ryhmiin toimenpiteet vaikuttavat eniten ja ovatko toimenpiteet siten sosiaalisesti perusteltavissa.

Toiseen tutkimuskysymykseen vastasimme luomalla kolme skenaariota, joissa runsaasti henkilöautoa käyttävien henkilöautomatkoja rajoitettiin ja oletettiin, että näillä matkoilla vastaajat siirtyivät käyttämään toista kulkutapaa. Skenaarioiden avulla henkilöautomatkojen 
vähennyspotentiaaliksi tunnistettiin $14-25$ prosenttia. Skenaarioiden laskennallinen henkilöautomatkojen vähenemä vastaa henkilöautomatkoille tunnistettua vaihtoehtoisen kulkutavan olemassaoloa. Vaihtoehtoinen kulkutapa henkilöautolla kuljettajana tehdyille matkoille oli olemassa useimmin niissä ryhmissä, joissa vähintään viisi henkilöautomatkaa päivässä tehneiden osuus oli suurin. Tämän perusteella voidaan todeta, että potentiaalia henkilöautomatkojen siirtämiseksi toiseen kulkutapaan on melko runsaasti.

Kulkutavan valinta ja siten myös henkilöautomatkojen vähentäminen on liikkujan itse tekemä päätös joukkoliikennetarjonnan, hyvien kävely- ja pyöräreittien olemassaolon, palveluiden sijainnin ja henkilökohtaisten rajoitteiden puitteissa. Jokaisen matkan kohdalla ihminen tekee neliporrasmallin mukaisesti neljä päätöstä, joista yksi on kulkutapapäätös (Kalenoja ym. 2008). Kuten Heinen ja Mattioli (2019) nostavat esille, kulkutapamuutoksia voidaan tehdä yksittäisten matkojen näkökulmasta, eikä auton käyttöä ole tarve lopettaa kokonaan. Tämän tutkimuksen skenaariot perustuvat ajatukseen, että matkoja ei tarvitse vähentää eikä kaikkea henkilöautoilua lopettaa, vaan ihmisten tulisi valita jokaiselle matkalleen kulkutapa erikseen eikä liikkua rutiinisidonnaisesti henkilöautolla. Koska tulosten perusteella ihmiset tunnistavat, että henkilöautolla tehdylle matkalle olisi usein löydettävissä vaihtoehtoinen kulkutapa, kulkutapaa olisi mahdollista vaihtaa. Jos liikkumisympäristö, palveluiden sijainti ja henkilökohtaiset tekijät sen mahdollistavat, muuttamalla kulkutapaa joillain matkoilla henkilöautosta joukkoliikenteeseen, kävelyyn tai pyöräilyyn jokaisen on mahdollista vaikuttaa liikenteen aiheuttamiin ympäristövaikutuksiin. Liikkumistottumusten muutoksilla liikenteen ympäristövaikutuksia voidaan vähentää nopeallakin aikataululla (Donald ym. 2014), sillä liikkumistottumuksia voidaan muuttaa heti, kun päätös muutoksesta on tehty.

Poliittisten päätösten avulla voidaan ohjata ihmisiä tekemään erilaisia päätöksiä liikkumisen suhteen. Maankäytön, asumisen ja liikenteen suunnittelua pyritään integroimaan ns. MALajattelun avulla, minkä lisäksi myös palveluja ja elinkeinotoimintaa integroimalla on pyritty löytämään ratkaisu maankäytön ja liikenteen yhteensovittamisen haasteisiin (MALPE) (Herneoja ym. 2018). Maankäytön avulla voidaan suunnitella asuinalueita, palvelukeskittymiä sekä työpaikkakeskittymiä siten, että matkat kodin ja työpaikan tai palveluiden välillä olisivat lyhyempiä, ja matkalle olisi siten helpompi valita jokin toinen kulkutapa auton sijaan.

Yhdyskuntarakennetta ja liikkumista voidaan tarkastella vyöhykeajattelun avulla jakamalla kaupunkirakenteet toiminallisesti jalankulku-, joukkoliikenne- ja autoiluvyöhykkeisiin. Jalankulku- ja joukkoliikennevyöhykkeet määritellään perustuen etäisyyteen keskustasta, asukastiheyteen ja joukkoliikenteen palvelutasoon. Kaukana keskustasta sijaitsevat tai jalankulku- tai joukkoliikennevyöhykkeen kriteerejä täyttämättömät alueet luokitellaan autoiluvyöhykkeiksi. Vyöhykkeiden avulla voidaan tunnistaa liikenteellisiä taitekohtia, jotka heijastavat liikenteen luonteen jaa koostumuksen muutoksia sekä maankäytön mahdollisuuksia. (Herneoja ym. 2018) Vyöhykeajattelun avulla voidaan myös tunnistaa ne alueet, joiden asukkailla olisi parhaimmat edellytykset siirtyä kulkemaan ainakin osa matkoista kestävämmillä kulkutavoilla.

Ihmisen valitseman asuinalueen joukkoliikennepalvelut ja jalankulku- ja pyöräväylät vaikuttavat siihen, koetaanko kestäviä kulkutapoja lainkaan vaihtoehdoksi, saati kilpailukykyiseksi vaihtoehdoksi, autoilulle. Eri kulkutapojen keskinäinen kilpailukyky onkin avainasemassa silloin, kun halutaan vähentää henkilöautomatkojen määrää arkiliikkumisessa. On vaikea erottaa, vaikuttavatko jotkut toimenpiteet siihen, ostetaanko auto vai siihen, käytetäänkö olemassa olevaa autoa liikkumisessa. Maankäytön avulla voidaan lyhentää matkoja ja lisätä muiden kulkutapojen houkuttelevuutta esimerkiksi tehokkaiden joukkoliikenneyhtyeyksien ja hyvien pyörä- ja kävelyväylien avulla, jolloin auto ei välttämättä ole enää ylivoimainen kulkutapa muihin nähden.

Koska auton valinta kulkutavaksi on usein kuitenkin myös psykologisiin tekijöihin liittyvää (Mokhtarian \& Salomon 2001; Lois \& López-Sáez 2009; Kaewkluengklom ym. 2017), joukkoliikenteestä on yritettävä tehdä houkuttelevampaa niille, jotka yhdistävät 
sosiaalisen statuksen käytettyyn kulkutapaan (Nordfjærn ym. 2016). Nordfjærn ym. (2019) mukaan autoilun kustannuksia kasvattamalla voidaan kannustaa kulkutavan vaihtoon, mutta kustannusten suuri kasvu voi johtaa liikkumisen eriarvoistumiseen. Esimerkiksi valtiovarainministeriön raportissaan (2020) ehdottama työpaikan pysäköintiedun verottaminen lisäisi autoilun kustannuksia, ja toisaalta ehdotettu työsuhdepolkupyörän verotuki (Valtiovarainministeriö 2020) voisi kannustaa kulkutavan vaihtoon työmatkoilla.

Bastianin ja Börjessonin (2015) mukaan henkilöauton käytön vähentämiseen voidaan ohjata esimerkiksi tiivistämällä yhdyskuntarakentamista, monipuolistamalla maankäyttöä ja tehostamalla joukkoliikennetarjontaa. Kaupunkialueella autoille asetetuille rajoitteilla yhdistettynä joukkoliikennetarjonnan parantamiseen ja edullisempiin lippuhintoihin voidaan kannustaa kulkutavan vaihtoon eriarvoistamatta liikkujaryhmiä. (Nordfjærn ym. 2019) Parhaita tuloksia joukkoliikenteen käytön lisäämiseksi voidaan saavuttaa keskittymällä niihin alueisiin, joissa joukkoliikenteen saavutettavuus on huono verrattuna siihen, että panostettaisiin niihin alueisiin, joissa joukkoliikennettä on jo hyvin saatavilla (Cui ym. 2020)

Tämän tutkimuksen pohjalta voidaan todeta, että ihmisten tietoisuuden lisääminen omista liikkumisvalinnoista olisi tärkeää, jotta ihmiset ymmärtäisivät, miten yksittäiset kulkutapavalinnat arkimatkoilla voivat vaikuttaa liikenteen kestävyyteen Suomessa. Haddadin ja de Nazellen (2018) mukaan liikkumisvalintoihin liittyvän ympäristötietoisuuden lisääminen on haastavaa. Ilmastonmuutokseen liittyvä viestintä on usein abstraktia, tieteellisesti epävarmaa ja monimutkaista. Viestinnässä käytetty kieli voi myös olla vaikeaa omaksua. Älypuhelimien sovelluksien avulla on saatu ihmisiä muuttamaan käyttäytymistään, esimerkiksi lisäämään päivittäisiä askelia askelmittarin myötä. Tämä osoittaa, että sovellukset voivat vaikuttaa ihmisten päätöksentekoon ja käyttäytymiseen, ja uusi teknologia tarjoaa suuren potentiaalin välittää tietoa omien liikkumistottumusten vaikutuksista ympäristöön. (Haddad \& de Nazelle 2018)

Liikenteen murroskohdat, kuten muutokset liikenteen palvelutarjonnassa tai käytettävissä olevassa infrastruktuurissa, voivat vaikuttaa siihen, miten liikkumiseen liittyviä valintoja tehdään jatkossa. Lucasin (2019) mukaan osa tutkijoista uskoo, että autonomiset autot, robottikuljetuspalvelut, yhteiskäyttöautot ja MaaS-palvelut (Mobility as a Service) voivat tarjota tulevaisuudessa uusia valintamahdollisuuksia liikkumisessa. Toisaalta joidenkin tutkijoiden mukaan vaikuttaa, että liikkumisen monipuolisemmat mahdollisuudet karttuvat jatkossa - ja jo nyt - hyväosaisille, ja toisaalta jo valmiiksi huonommassa asemassa olevat tulevat kärsimään yhä enemmän saavutettavuuteen liittyvistä ongelmista. Tulevaisuudessa on edelleen paljon kotitalouksia, joilla ei ole varaa hankkia autoa, saati sähköautoa. Yhteiskäyttöautot ovat myös monien heikommassa asemassa olevien ulottumattomissa. (Lucas 2019)

Tässä tutkimuksessa tutkittiin väestötasolla, miten eri tulo- ja perheryhmissä liikutaan henkilöliikennetutkimuksen valossa, mutta kotitalouden tulot eivät aina mittaa tarkasti sitä, miten paljon henkilöllä itsellään on käytössä rahaa liikkumiseen. Tulosten tarkastelussa on myös otettava huomioon, että matkaketjuissa henkilöauton käyttöä määrää usein matkaketjun ensimmäiselle matkalle valittu kulkutapa. Henkilöauton käytön vähentämisen mahdollisuudet ovat realistisimmat siis niillä matkoilla, joissa henkilöauto on valittu erityisesti tiettyä matkaa varten, vaikka muitakin kulkutapoja olisi ollut valittavana. Matkaketjujen tutkiminen yhdistettynä liikkumiseen käytetyn ajan arvottamiseen erilaisissa perhe- ja tuloryhmissä tarjoaisi liikkumiskäyttäytymisestä ja kulkutavan valinnasta lisää tietoa. Olisi myös hyvä tutkia tarkemmin, mitkä keinot koettaisiin ihmisten keskuudessa tehokkaimmiksi ja hyväksyttävimmiksi kannustimiksi siirtyä käyttämään kestävämpiä kulkutapoja autoilun sijaan, ja toisaalta mitkä asiat arkiliikkumisessa koetaan sellaisiksi, jotka vaikeuttavat kestävien kulkutapojen käyttöä. 


\section{Kiitokset}

Kirjoittajat haluavat kiittää Koneen Säätiötä tutkimuksen rahoituksesta (apurahan numero b4b919) ja Liikenne- ja viestintävirasto Traficomia HLT-aineiston käyttömahdollisuudesta sekä Riku Viriä Tampereen yliopiston Liikenteen tutkimuskeskus Vernestä aineiston alkuvalmisteluista. Kirjoittajat haluavat myös kiittää nimettömiä arvioijia sekä toimittajia arvokkaista kommenteista ja parannusehdotuksista.

\section{Lähteet}

Banister, D. (2018) Inequality in Transport. Alexandrine Press, Oxfordshire.

Bastian, A., \& Börjesson, M. (2015) Peak car? Drivers of the recent decline in Swedish car use. Transport Policy 42 94-102. http://dx.doi.org/10.1016/j.tranpol.2015.05.005

Bastian, A., Börjesson, M. \& Eliasson, J. (2016) Explaining "peak car" with economic variables. Transportation Research Part A 88 236-250. http://dx.doi.org/10.1016/j.tra.2016.04.005

Bastian, A. (2017) Explaining Trends in Car Use. Doctoral Thesis. KTH Royal Institute of Technology. School of Architecture and the Built Environment. Department of Transport Science. Stockholm, Sweden 2017.

Bastian, A., Börjesson, M. \& Eliasson, J. (2017) Response to Wadud and Baierl: “Explaining 'peak car' with economic variables: An observation Transportation Research Part A 95 386-389. http://dx.doi.org/10.1016/j. tra.2016.11.001

Bliemer, M.C.J., Raadsen, M.P.H., Brederode, L.J.N., Bell, M. G.H. \& Wismans, L.J.J. \& Smith, M.J. (2017) Genetics of traffic assignment models for strategic transport planning. Transport Reviews, 37(1) 56-78. https://doi.org/10.1080/01441647.2016.1207211

Bouscasse, H., Joly, I. \& Bonnel, P. (2018) How does environmental concern influence mode choice habits? A mediation analysis. Transportation Research Part D 59 205-222. https://doi.org/10.1016/j.trd.2018.01.007

CBT (2011) Campaigner's guide to: Reducing the need to travel. Campaign for better transport. October 2011. https://bettertransport.org.uk/sites/default/files/research-files/reducing-the-need-to-travel-guide.pdf

Colli, E. (2020) Towards a mobility transition? Understanding the environmental impact of Millennials and Baby Boomers in Europe. Travel Behaviour and Society 20 273-289. https://doi.org/10.1016/j.tbs.2020.03.013

Cooper, J., Ryley, T. \& Smyth, A. (2001) Contemporary lifestyles and the implications for sustainable development policy: Lessons from the UK's Most Car Dependent City, Belfast. Cities 18(2) 103-113. https://doi.org/10.1016/S0264-2751(00)00062-7

Cui, B., Boisjoly, G., Miranda-Moreno, L. \& El-Geneidy, A. (2020) Accessibility matters: Exploring the determinants of public transport mode share across income groups in Canadian cities. Transportation Research Part D 80 102276. https://doi.org/10.1016/j.trd.2020.102276

DeCicco, J.M. (2013) Factoring the car-climate challenge: Insights and implications. Energy Policy 59 382-392. http://dx.doi.org/10.1016/j.enpol.2013.03.052

Delbosc, A. \& Currie, G. (2011) Transport problems that matter - social and psychological links to transport disadvantage. Journal of Transport Geography 19 170-178. https://doi.org/10.1016/j.jtrangeo.2010.01.003

De Vos, J. \& Witlox, F. (2017) Travel satisfaction revisited. On the pivotal role of travel satisfaction in conceptualising a travel behaviour process. Transportation Research Part A 106 364-373. http://dx.doi. org/10.1016/j.tra.2017.10.009

Donald, I.J., Cooper, S.R. \& Conchie, S.M. (2014) An extended theory of planned behaviour model of the psychological factors affecting commuters' transport mode use. Journal of Environmental Psychology 40 39-48. http://dx.doi.org/10.1016/j.jenvp.2014.03.003

Haddad, H. \& de Nazelle, A. (2018) The role of personal air pollution sensors and smartphone technology in changing travel behaviour. Journal of Transport \& Health 11 230-243. https://doi.org/10.1016/j. jth.2018.08.001

Heinen, E. \& Mattioli, G. (2019) Does a high level of multimodality mean less car use? An exploration of multimodality trends in England. Transportation 46 1093-1126. https://doi.org/10.1007/s11116-017-9810-2

Herneoja, A., Valli, R., Lautso, J., Lindroos, K. \& Seppä, I-M. (2018) Liikenteen ja maankäytön ybteistyömenetelmien kehittäminen. Liikennevirasto, liikenne- ja maankäyttöosasto. Helsinki 2018. Liikenneviraston tutkimuksia ja selvityksiä 53/2018.

Hirvonen, J. \& Vanhatalo, M. (2018) Ympäristöasenteet ja kaupunkikehitys Helsingissä ja Vantaalla. Tutkimuksia 2018:1. Helsingin kaupunki, kaupunginkanslia, kaupunkitutkimus ja -tilastot. Edita Prima Oy, Helsinki. https://www.hel.fi/hel2/tietokeskus/julkaisut/pdf/18_02_02_Tutkimuksia_1_Hirvonen_Vanhatalo.pdf

HSL (2011) Helsingin seudun työssäkë̈ntialueen liikenne-ennustemallit 2010. HSL:n julkaisuja 33/2011. HSL Helsingin seudun liikenne. 
Kaewkluengklom, R., Satiennam, W., Jaensirisak, S. \& Satiennam, T. (2017) Influence of psychological factors on mode choice behaviour: Case study of BRT in Khon Kaen City, Thailand. Transportation Research Procedia 25 5072-5082. https://doi.org/10.1016/j.trpro.2017.05.213

Kalenoja, H. \& Keränen, M. (2012) Kuopion alueen liikennemalli 2012. Mallin rakenne, nykytilannekuvaus ja perusennuste vuodelle 2030. Tampereen teknillinen yliopisto. Liikenteen tutkimuskeskus Verne. Tutkimusraportti 80.

Kalenoja, H., Vihanti, K., Voltti, V., Korhonen, A. \& Karasmaa, N. (2008) Liikennetarpeen arviointi maankäytön suunnittelussa. Suomen ympäristö 27/2008. Ympäristöministeriö. Alueidenkäytön osasto. Edita Prima Oy. Helsinki. http://hdl.handle.net/10138/38345

Kotval-K, Z. \& Vojnovic, I. (2016) Analysis. A socio-ecological exploration into urban form: The environmental costs of travel. Ecological Economics 128 87-98. http://dx.doi.org/10.1016/j.ecolecon.2016.04.009

Liikennevirasto (2016) Henkilöliikennetutkimus 2016. Liikennevirasto, Liikenne ja maankäyttö. Helsinki 2018. Liikenneviraston tilastoja 1/2018. https://julkaisut.vayla.fi/pdf8/lti_2018-01_ henkiloliikennetutkimus_2016_web.pdf

Lindroos, T.J. \& Ekholm, T. (2016) Taakanjakosektorin päästökehitys ja päästövähennystoimet vuoteen 2030. VTT Technology 245. Teknologian tutkimuskeskus VTT Oy. http://urn.fi/URN:ISBN:978-951-38-8393-5

Lois, D. \& López-Sáez, M. (2009) The relationship between instrumental, symbolic and affective factors as predictors of car use: A structural equation modeling approach. Transportation Research Part A 43 790-799. https://doi.org/10.1016/j.tra.2009.07.008

Lucas, K. 2012. Transport and social exclusion: Where are we now? Transport Policy 20 105-113. https:// doi:10.1016/j.tranpol.2012.01.013

Lucas, K., Bates, J., Moore, J. \& Carrasco, J.A. (2016) Modelling the relationship between travel behaviours and social disadvantage. Transportation Research Part A 85 157-173. http://dx.doi.org/10.1016/j.tra.2016.01.008

Lucas, K. (2019) A new evolution for transport-related social exclusion research? Journal of Transport Geography 81 102529. https://doi.org/10.1016/j.jtrangeo.2019.102529

LVM (2018) Toimenpideohjelma biilettömään liikenteeseen 2045. Liikenteen ilmastopolitiikan työryhmän loppuraportti. Liikenne- ja viestintäministeriön julkaisuja 13/2018. Liikenne- ja viestintäministeriö. http:// urn.fi/URN:ISBN:978-952-243-559-0

Marsden, G., Anable, J., Chatterton, T., Docherty, I., Faulconbridge, J., Murray, L., Roby, H. \& Shires, J. (2020) Studying disruptive events: Innovations in behaviour, opportunities for lower carbon transport policy? Transport Policy 94 89-101. https://doi.org/10.1016/j.tranpol.2020.04.008

Mokhtarian, P.L. \& Salomon, I. (2001) How derived is the demand for travel? Some conceptual and measurement considerations. Transportation Research Part A 35 695-719. https://doi.org/10.1016/S09658564(00)00013-6

Nilsson, M. \& Küller, R. (2000) Travel behaviour and environmental concern. Transportation Research Part D 5 211-234. https://doi.org/10.1016/S1361-9209(99)00034-6

Nordfjærn, T., Simsekoglu, Ö. \& Rundmo, T. (2016) Active transport, public transport and electric car as perceived alternatives in a motorized Norwegian sample. Transportation Research Part F 42 70-79. http:// dx.doi.org/10.1016/j.trf.2016.07.001

Nordfjærn, T., Lind, H.B., Şimşekoğlu, Ö., Jørgensen, S.H., Lund, I.O. \& Rundmo, T. (2019) The role of social cognition in perceived thresholds for transport mode change. Transport Policy 83 88-96. https:// doi.org/10.1016/j.tranpol.2019.09.006

Pastinen, V., Rantala, A. \& Lehto, H. (2018) Henkilöliikennetutkimus 2016. Tekninen raportti. Liikennevirasto, Liikenne ja maankäyttö. Helsinki 2018. Liikenneviraston tutkimuksia ja selvityksiä 14/2018. https:// julkaisut.vayla.fi/pdf8/lts_2018-14_henkiloliikennetutkimus_tekninen_web.pdf

Pöllänen, M., Mäkelä, T., Nykänen, L., Liimatainen, H. \& Mäntynen, J. (2015) Liikenteen mark.kinat Suomessa. Trafin tutkimuksia 16/2015. Liikenteen turvallisuusvirasto Trafi.

Sampleton, L., Sorrel, S. \& Schwanen, T. (2017) Peak car and increasing rebound: A closer look at car travel trends in Great Britain. Transportation Research Part D 53 217-233. http://dx.doi.org/10.1016/j. $\operatorname{trd} .2017 .03 .025$

Shliselberg, R. \& Givoni, M. (2017) Motility as a policy objective. Transport Reviews. https://doi.org/10.108 $0 / 01441647.2017 .1355855$

Tampere (2014) Tampereen raitiotien yleissunnnitelma. Liikenne-ennusteet. Työraporttiluonnos 30.5.2014. https:// www.tampere.fi/liitteet/1/PdQVklK3A/liikenneennusteettyoraporttiluonnos.pdf

Tao, S., He, S.Y. \& Thøgersen, J. (2019) The role of car ownership in attitudes towards public transport: A comparative study of Guangzhou and Brisbane. Transportation Research Part F 60 685-699. https://doi. org/10.1016/j.trf.2018.12.005

Valtiovarainministeriö (2020) Liikenteen verotuksen undistamista selvittävän työryhmän väliraportti. Valtiovarainministeriön julkaisuja 2020:40. http://urn.fi/URN:ISBN:978-952-367-317-5

Van Acker, V., Mokhtarian, P.L. \& Witlox, F. (2014) Car availability explained by the structural relationships 
between lifestyles, residential location, and underlying residential and travel attitudes. Transport Policy 35 88-99. http://dx.doi.org/10.1016/j.tranpol.2014.05.006

Wadud, Z. \& Baierl, M. (2017) Explaining "peak car" with economic variables: A comment. Transportation Research Part A 95. 381-385. http://dx.doi.org/10.1016/j.tra.2016.11.002

Yen, B.T.H., Mulley, C. \& Burke, M. (2019) Gamification in transport interventions: Another way to improve travel behavioural change. Cities 85 140-149. https://doi.org/10.1016/j.cities.2018.09.002

Ympäristöministeriö (2017) Valtioneuvoston selonteko keskipitkën aikavälin ilmastopolitiikan suunnitelmasta vuoteen 2030 - Kobti ilmastoviisasta arkea. Ympäristöministeriön raportteja 21/2017. http://urn.fi/ URN:ISBN:978-952-11-4748-7

Zhao, X., Ke, Y., Zuo, J., Xiong, W. \& Wu, P. (2020) Evaluation of sustainable transport research in 20002019. Review. Journal of Cleaner Production 256 120404. https://doi.org/10.1016/j.jclepro.2020.120404 